\title{
SZERSZÁMGÉPEK KARBANTARTÁSI RENDSZEREI
}

\author{
Tóth Dániel \\ tanársegéd, Miskolci Egyetem, \\ Szerszámgépészeti és Mechatronikai Intézet, Szerszámgépek Intézeti Tanszéke \\ 3515 Miskolc, Miskolc-Egyetemváros, e-mail: toth.daniel@uni-miskolc.hu \\ Szilágyi Attila \\ egyetemi docens, Miskolci Egyetem, \\ Szerszámgépészeti és Mechatronikai Intézet, Szerszámgépek Intézeti Tanszéke \\ 3515 Miskolc, Miskolc-Egyetemváros, e-mail: szilagyi.attila@ uni-miskolc.hu

\section{Simon Gábor} \\ mesteroktató, Miskolci Egyetem, \\ Szerszámgépészeti és Mechatronikai Intézet, Szerszámgépek Intézeti Tanszéke \\ 3515 Miskolc, Miskolc-Egyetemváros, e-mail: simon.gabor@uni-miskolc.hu
}

\begin{abstract}
Absztrakt
A szerszámgépek bonyolult mechatronikai eszközök. A modern szerszámgépek üzemeltetéséhez speciális müszaki ismeretek szükségesek. Ezen eszközök üzemeltetése során központi kérdés a megfelelö karbantartási stratégia kiválasztása, amely egyensúlyt teremt a költségek és a rendelkezésre állás között. Jelen cikk szerszámgép karbantartási rendszereket mutat be.
\end{abstract}

Kulcsszavak: karbantartási rendszerek, szerszámgép, élettartam gazdálkodás

\begin{abstract}
Machine tools are complicated mechatronic devices. Operating modern machine tools needs professional technical knowledge. Choosing the correct maintenance strategy that makes balance between the costs and the availability is the central question during the operation of these devices. This paper presents maintenance systems of machine tools.
\end{abstract}

Keywords: maintenance systems, machine tool, lifetime management

\section{Bevezetés}

Az elmúlt évtizedekben nagymértékben átalakult a magyar ipar gyártóeszközeinek összetétele, amely fơként a számjegyvezérlésü szerszámgépek elterjedésében mutatkozott meg. Ezzel egyidejűleg a cégeknél alkalmazott gyártási stratégiák is nagyban megváltoztak. Ez a helyzet a korábbiakhoz képest új kihívások elé állítja gyártóeszközök karbantartásával foglalkozó szakembereket. Ez egyrészt a gyártmánystruktúra időszakos megváltozása miatt a gyártóeszközök rendszeres áttelepítésében, másrészt a konkrét gyártmányokhoz igazodó gyártási sorba szervezett gyártóeszközök nagyobb üzembiztonságának biztosításában mutatkozik meg. Az új alkalmazási irányvonalaknak megfelelően a szerszámgép fejlesztők a korszerủ CNC szerszámgépeket merevebb gépvázzal tervezik és a gépek fö funkcióit csereszabatos részegységek felhasználásával igyekeznek megvalósítani. 


\section{Karbantartási rendszerek}

Az utóbbi időben a gyártóeszközökkel kapcsolatos karbantartási feladatok megítélése jelentősen megváltozott. A karbantartási szemléletek átalakulását mutatja az 1. ábra.

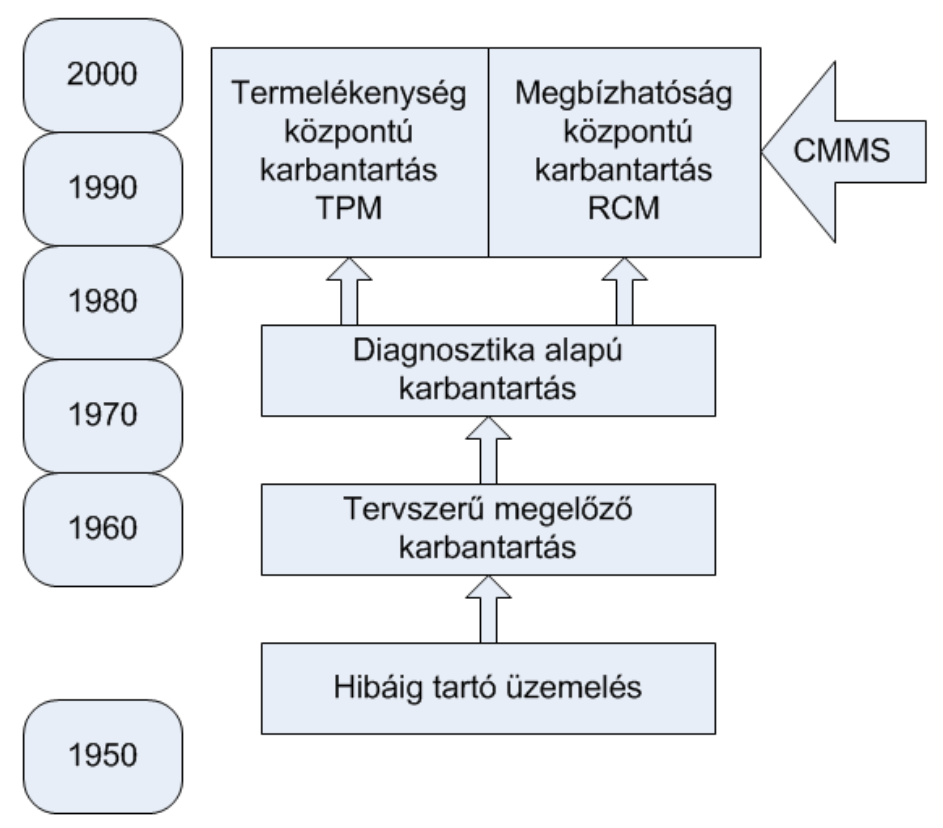

\section{1. ábra. A karbantartási szemléletek változása}

Az 1950-es évekig voltaképpen nem lehetett a mai értelemben vett karbantartásról beszélni, mert a technológiai berendezéseken csak az egyszerübb karbantartási feladatokat (pl. kenések, tisztítások, stb.) végezték el. Ebből kifolyólag a gépleállások váratlanul következtek be. Az első karbantartási stratégia a TMK (tervszerü megelőző karbantartás) volt, mely a váratlan gépleállások számát tudta ugyan csökkenteni, de gazdaságtalansága miatt újabb lehetöségeket kellett keresni [1]. Ezután a következő szint az 1970-es években kialakuló, a mért értékekre támaszkodó, műszeres diagnosztikán alapuló karbantartási stratégia volt. Ezen szemlélet alkalmazásával a nagy értékủ részegységek, alkatrészek használata élettartamuk végéig biztosítható, mindazonáltal használatával kiemelkedő megtakarítás csak különleges esetekben érhető el a szükséges drága eszközrendszer miatt. A költséges számjegyvezérlésủ szerszámgépek esetén azonban e diagnosztikai módszerek alkalmazása gazdaságos megoldást jelenthet, mivel a rendszer egyes elemei a korszerủ szerszámgépeken más funkciók ellátása miatt már különben is rendelkezésre áll. A Miskolci Egyetem, Szerszámgépek Tanszéke az 1980-as években a „VILMOS” szerszámgép-felügyeleti rendszer fejlesztése révén kapcsolódott be a magyar szerszámgépgyárak kutatási feladatainak megoldásába [2]. Az állapotfelügyelet csak eszköz a karbantartási célok megvalósítása érdekében, mivel olyan lokális karbantartási információt ad, amit a karbantartási szervezetnek kell arra a gyártási rendszerre származtatni, melyben a diagnosztizált szerszámgép müködik. Az 1970-as években kialakultak és az 1990-es évekre széles körúen elterjedtek a vállalati karbantartás rendszer szintü szemléletei, melyek közül a megbízhatóság központú RCM (reliability centered maintenance) és a termelékenység központú TPM (total productive maintenance) rendszerek voltak a legkedveltebbek. A TPM a Toyota termelési rendszer részeként jött létre, mely témakörrel 
kapcsolatban először Seiichi Nakajima publikált [3]. A TPM egy rendkívül rugalmas komplex rendszer, melynek egyszerüsített szerkezetét mutatja a 2 . ábra.

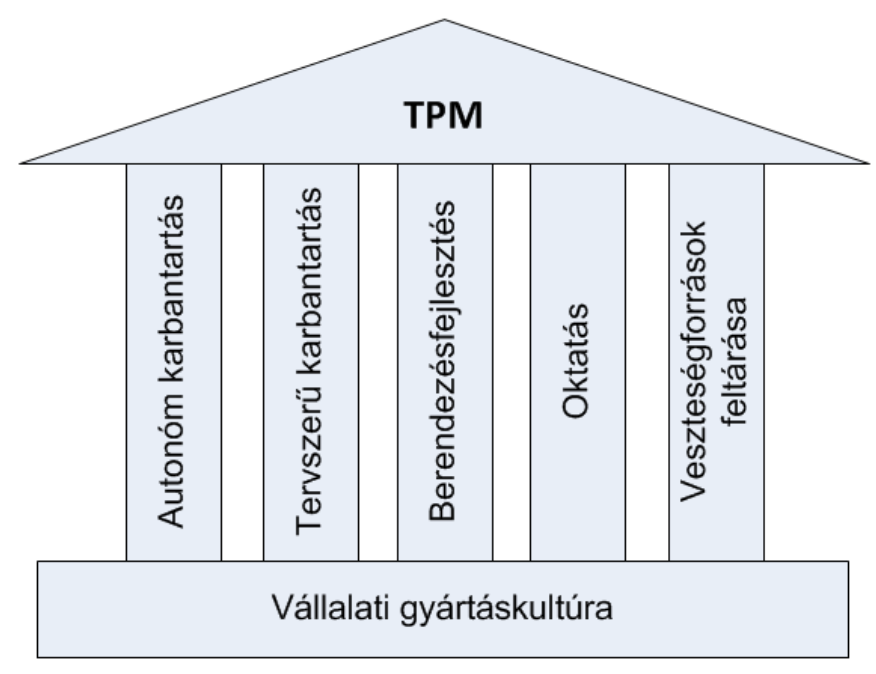

2. ábra. A TPM struktúrája [3]

A TPM rendszer az 5S (seiri: szelektálás; seiton: elrendezés; seiso: takaritás; seiketsu: rendszeresség; shitsuke: fegyelem) módszernek megfelelő gyártáskultúrájú vállalatoknál müködik eredményesen. A TPM legfontosabb feladata a hatékonyság szempontjából optimális termelöszervezet kiépítése, a termelékenység növelése, a fennakadások és selejt nélküli termelés, melyhez a géppark teljes tervezett élettartamát átfogó és kiterjedt megelőző karbantartás megszervezésére van szükség. A megbízhatóság központú karbantartás $(R C M)$ az üzemfenntartás hiányosságaira visszavezethető hibák csökkentésén keresztül az üzemfenntartási költségeinek csökkentésére összpontosít. Míg a korábbi karbantartási szemléletek a géphibák megelőzését, tervezettnél korábbi bekövetkezését, vagy elörejelzését tartották fontosnak, addig az RCM, egy elemzési módszeren keresztül a hibák következményeit igyekszik feltárni és csökkenteni. Az RCM merevebb, zártabb rendszer, mint a TPM filozófiára épülő karbantartási rendszerek, melyek hatékonyabban képesek magukba integrálni a modern karbantartási eszközrendszereket és módszereket [4].

A forgácsoló szerszámgépek hatékony üzemeltetésének egyik feltétele, hogy a bevezetett karbantartási rendszer felügyelete alatt müködjön, melynek legfontosabb építőkövei a dinamikus paraméterekkel beszabályozott karbantartási utasítások. A dinamikus paraméterezés azt jelenti, hogy számos paramétert figyelve ( $p l$. a berendezés igénybevétele, a gépkezelök képzettsége, karbantartó személyzet kapacitása, stb.) a karbantartási rendszerböl nyert statisztikai elemzésekre alapozva meg kell találni a karbantartásra fordított idők olyan minimális értékét, mely még képes biztosítani a gépek szükséges rendelkezésre állását. A CMMS (computerized maintenance management system) nem egy önálló karbantartási rendszer, hanem olyan számítógépes eszköz, mely információkat tud szolgáltatni egyes vezetői döntésekhez és hatékonyan képes segíteni a karbantartási személyzet munkáját. Mivel a CMMS által kezelt feladatok közvetlenül a konkrét gyártási folyamatokhoz kapcsolódnak, a gyakorlatban nem lehet univerzális, minden vállalat igényét maximális mértékben kielégítő szoftvereket fejleszteni [4]. 


\section{3. Összefoglalás}

Egy ország iparának fejlettségét lényegesen befolyásolja az alkalmazott gyártóeszközök müszaki színvonala. A karbantartási személyzet munkáját támogató korszerủ karbantartási rendszerek mára már elterjedtek Magyarországon. A korszerü számjegyvezérlésű szerszámgépek karbantartási feladatainak megtervezése, megszervezése és végrehajtása a gépipari átlagtól jelentősen magasabb felkészültséget igényel. A jellemzően számjegyvezérlésü szerszámgépeket használó vállalatok számára nagy támogatást nyújthat egy olyan CMMS programcsomag, mely elsősorban a korszerü szerszámgépek karbantartási feladatait segíti.

\section{Köszönetnyilvánítás}

A cikkben ismertetett kutató munka az EFOP-3.6.1-16-2016-00011 jelü „Fiatalodó és Megújuló Egyetem - Innovatív Tudásváros - a Miskolci Egyetem intelligens szakosodást szolgáló intézményi fejlesztése" projekt részeként - a Széchenyi 2020 keretében - az Európai Unió támogatásával, az Európai Szociális Alap társfinanszírozásával valósul meg.

\section{Irodalom}

[1] Péczely, Gy.: A karbantartás korszerü irányzatai. Karbantartás és diagnosztika, II., pp: 4 - 46. 2000.

[2] Erdélyi, F., Sántha, Cs., Csáki, T.: A "VILMOS" - egy CNC-be integrált szerszámgép felügyeleti rendszer. XI. Szerszámgép Kollokvium, Budapest, 1989.

[3] Nakajima, S.: Introduction to TPM. Productivity Press, Cambridge, 1988.

[4] Takács, Gy., Hegedűs, Gy., Szilágyi, N.: Szerszámgépek számitógéppel segitett karbantartása. GÉP 63 (3) pp. 31-34. 2012. 